\title{
A GEOTERMIKUS ENERGIA SZEREPE A MAGYAR HŐELLÁTÁSBAN
}

\section{THE ROLE OF GEOTHERMAL ENERGY IN THE HUNGARIAN HEAT SUPPLY}

\author{
Nyikos Attila ${ }^{1}$, Tóth Anikó Nóra ${ }^{2}$ \\ ${ }^{1}$ nemzetközi kapcsolatokért felelős elnökhelyettes, Magyar Energetikai és Közmü-szabályozási Hivatal, Budapest \\ nkeht@mekh.hu \\ 2PhD, egyetemi docens, Miskolci Egyetem Kőolaj és Földgáz Intézet Gázmérnöki Tanszék, \\ a Környezettudományi Elnöki Bizottság (KÖTEB) Energetika és Környezet Albizottságának tagja
}

\begin{abstract}
ÖSSZEFOGLALÁS
A geotermikus energia alkalmazása mellett számos nyomós érv szól. Ezek között első helyen kell hogy szerepeljenek Magyarország kedvező természeti adottságai, amelyek jelentősen meghaladják az európai átlagot, s nemcsak a jelenben, de a távolabbi jövőben is adottak a hatékony geotermikusenergia-termelés feltételei. A rezervoárok nem csupán megfelelő hőmérsékletűek s a felszínhez viszonylag közeliek, hanem a bennük tárolt óriási energiamennyiség hosszú időre fedezheti az energiaspektrumnak a geotermikus forrásból kielégíthető hányadát.

Magyarország szinte valamennyi fosszilis energiahordozóból nagymértékủ behozatalra szorul. Energiaimportunk meghaladja a 70\%-ot. A geotermikus energia viszont teljes egészében hazai, és a 435 PJ-os fütési-hűtési energiaigények kielégítésére hosszú távon át alkalmas lehet. Így az energiaimport csökkentésének, a független magyar energiaellátás kialakításának hatékony eszközévé válhat.

A geotermikus energia alkalmazásának további előnye, hogy független a fosszilis energiahordozók gyakran spekulációs céllal gerjesztett áringadozásaitól és általában az externális költségváltozástól. Ezzel a magyar energiapiac stabilitásának kialakításában fontos szerepet kaphat.
\end{abstract}

\section{ABSTRACT}

There are many compelling arguments for using geothermal energy. Paramount of them is that it exploits Hungary's rich geothermal reservoirs, which are considerably warmer, closer to the surface and therefore can be more easily exploited than the European average. Both now and in the foreseeable future, Hungary's geothermal resources can satisfy the conditions required for efficient energy production. In the long term, the tremendous amount of energy stored in our geothermal reservoirs could potentially meet a major part of the country's energy demand.

Another very important consideration is Hungary's current dependence on fossil energy, more than $70 \%$ of which is imported. By contrast, geothermal energy is completely homegrown and can satisfy up to $435 \mathrm{PJ}$ of our heating and cooling needs well into the future. To that extent, geothermal energy is a powerful tool for reducing energy imports and achieving the national goal of energy independence. 
In the long term, geothermal energy would be more affordable and less likely to undergo major price fluctuations. Unlike oil and gas imports, the market price for geothermal energy produced in Hungary cannot be easily manipulated by external factors. This can play a major role in establishing the stability of the Hungarian energy market.

Kulcsszavak: nemzeti energiastratégia, cselekvési terv, energiaigény

Keywords: national energy strategy, action plan, energy demand

\section{A GEOTERMIKUS ENERGIA TERMELÉSE ÉS HASZNOSÍTÁSA MAGYARORSZÁGON}

Magyarországon a geotermikus energia termelése a hévizek energiatartalmának hasznosításán alapul. Ehhez járul a felszín alatti sekély, 200 méternél nem mélyebb rétegek energiatartalmának felszínre hozatala víztermelés nélküli talajszondák és hőszivattyúk révén. Itt jegyezzük meg a megújuló energia hasznosításával kapcsolatban, hogy például az Amerikai Egyesült Államokban ma már a hőszivattyús fütés a legelterjedtebb fütési technológia az új lakóépületekben, olcsósága, egyszerüsége és szinte igénytelen karbantartási szükséglete miatt.

A hévízkutak száma hazánkban közel 1700. A Magyar Bányászati és Földtani Hivatal adatközlése alapján 2015-ben a kitermelt hévíz mennyisége 24,608 millió $\mathrm{m}^{3}$ volt. A termelt hömennyiség 2509 TJ. Termálkútjaink 40\%-a, mintegy 600 kút, balneológiai célú. A balneológiai célú kutak elméleti termálkapacitása $352 \mathrm{MW}_{\mathrm{t}}$, ami $3912 \mathrm{TJ} / \mathrm{e} v$ mennyiséget jelent. Igen sajnálatos, hogy ez a hőkapacitás csupán elméleti, mivel fürdőink nagy része energetikai célra csak igen kis mértékben, vagy egyáltalán nem hasznosítja a termálvíz hőtartalmát (Tóth, 2016).

Másik hagyományos és igen jelentős ága a geotermikus energia hazai felhasználásának az üvegházak és fóliasátrak fütése termálvízzel. Mintegy ötszáz kútból közel 11 millió $\mathrm{m}^{3}$ vizet termelünk ki, amellyel több mint 70 hektár üvegház és 260 hektár talajfütésủ fóliasátor höellátása biztosított. Több mint ötven helyen termálvíz füt horgásztavakat, halastavakat, csirke-, pulyka-, sertés-, sőt csigafarmokat, mezőgazdasági hasznosításként. A mezőgazdasági célra kitermelt hévizeink becsült kapacitása 3413 TJ.

\section{GEOTERMIKUS ENERGIAELLÁTÁSRA ALKALMAS CÉL-ÉS HÖPIACOK AZONOSITTÁSA}

Magyarországon 2017-ben indult kísérleti jelleggel geotermikus alapú áramtermelés Tura térségében, amelyről egyelőre nincs számottevő információ. Termálvizeinket gyakorlatilag közvetlen módon, azaz hőenergiaként hasznosítjuk. Magyarországon kilencvennégy települést látnak el távhőszolgáltatással a társa- 
ságok, ez 656 ezer lakossági fogyasztót és mintegy húszezer ipari és egyéb fogyasztót jelent.

A KSH 2016-os adatai szerint hazánkban 2809 település van. A települések népsürüsége tájegységenként igen nagy szórást mutat. Egyértelmüen a legnagyobb piacot a föváros jelenti, ahol több távfütőrendszer is üzemel. A városi agglomerátumok jelentik az intenzív piacot, és a hőigények egyenesen arányosak a népesség mértékével.

Az összes hazai településböl csak huszonhét helységben - Barcs, Bóly, Budapest, Cserkeszőlö, Csongrád, Debrecen, Gárdony, Győr, Hódmezővásárhely, Jászkisér, Kistelek, Makó, Mezőberény, Miskolc, Mórahalom, Mosonmagyaróvár, Nagyatád, Szarvas, Szeged, Szentes, Szentlőrinc, Szigetvár, Szolnok, Tamási, Törökszentmiklós, Vasvár, Veresegyház - hasznosítják a termálvizet fütési célra. Távfütésre pedig huszonegy település (Barcs, Bóly, Cserkeszőlő, Csongrád, Gárdony, Győr, Hódmezővásárhely, Kistelek, Makó, Miskolc, Mórahalom, Nagyatád, Orosháza, Szarvas, Szeged, Szentes. Szentlőrinc, Szigetvár, Szolnok, Vasvár, Veresegyház) hasznosítja a termálhőt (1. ábra).

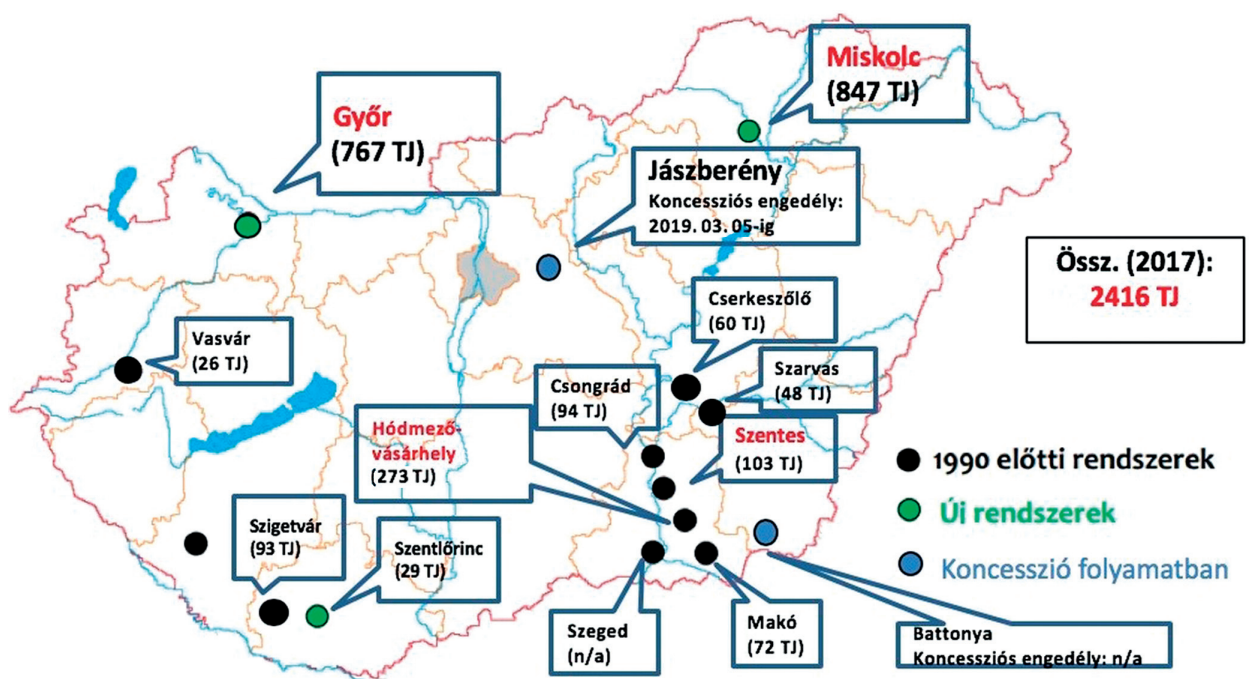

1. ábra. Geotermikus távfütési rendszerek Magyarországon. Zárójelben a geotermikus rendszerből a tárgyévben kinyert hasznosítható hőmennyiség 2017-ben (TJ). A legtöbb távhőrendszer a lakossági ellátást szolgálja, a győri távhőrendszer azonban ipari fogyasztót is ellát

(saját szerkesztés)

2015-ben a távhőcélra kiadható teljes 6740 MW hőteljesítményből csak mintegy 186 MW kapacitást biztosított geotermikus hőforrás, a többit hagyományos (túlnyomórészt földgázt, kisebb részben biomasszát, szenet és egyéb energiahordozót 
hasznosító) távhőerőmű biztosította. A teljes $6500 \mathrm{MW}$ piaci potenciál becslésünk szerint mintegy 50-70\%-ában reális alternatíva lehet a hagyományos höerőművek kiváltása geotermikus hőtermeléssel.

\section{LEGJELENTŐSEBB KIHÍVÁSOK A GEOTERMIKUS ENERGIA HASZNOSÍTÁSÁNAK JÖVÖBELI FEJLŐDÉSÉBEN}

A geotermikus energia jövője erősen függ attól, hogy milyen mértékben lehet a geotermikus erőművek telepítését felgyorsítani, mivel világviszonylatban is megfigyelhető a más megújuló energiaforrások hasznosításának gyors fejlődése. Így a szélenergia hasznosítása $25 \mathrm{GW}_{\mathrm{e}}$, a napenergia $6 \mathrm{GW}_{\mathrm{e}}$ kapacitással nő évente. Mindeközben a geotermikus áramtermelés növekedése $2 \mathrm{GW}_{\mathrm{e}}$ /év alatt marad, de egyesek szerint az egyre nagyobb geotermikus kapacitásfaktor szükségszerüvé teszi a geotermikus áramtermelés felgyorsulását.

A 103/2011. (VI. 29.) kormányrendelet az ásványi nyersanyag és a geotermikus energia természetes előfordulási területek komplex érzékenységi és terhelhetöségi vizsgálatáról jogszabály alapján a Magyar Bányászati és Földtani Szolgálat (MBFSZ) társintézmények és közigazgatási szervek közremüködésével elkészíttette a geotermikus koncesszióra javasolt tizenhat terület érzékenység-terhelhetőség vizsgálati tanulmányát.

A különböző villamosenergia-elöállítási módok, köztük a geotermia összehasonlításához érdemes felhasználni a Levelized Cost of Electricity (LCOE; a projekt teljes élettartamára vetített kiegyenlített, fajlagos termelési egységköltség) valamint a Levelized Avoided Cost of Electricity (LACE; a projekt teljes élettartamára vetített kiegyenlített, fajlagos elkerült egységköltség) fogalmakat. Az LCOE-mérőszám azt mutatja meg, hogy az erőmủ teljes élettartamát tekintve mennyibe kerül $1 \mathrm{kWh}$ villamos energia elóállítása, és ebbe beszámítanak minden építési, fenntartási, üzemeltetési és leszerelési költséget, a beruházáshoz szükséges tőkét és költségeit, az üzemanyag árát, valamint az erőmü kihasználtsági fokát (Tester et al., 2006).

\section{NEMZETI ENERGIASTRATÉGIA}

A LACE-mérőszám azt mutatja meg, hogy mekkora a hálózatban annak a villamos energiának az előállítási költsége (egy már meglévő vagy másik új infrastruktúrával), amelynek a megtermelésére az adott villamos energia infrastruktúra beruházást tervezték. Ha az adott beruházásra vonatkozó LACE nagyobb, mint az LCOE, akkor a beruházás gazdaságilag kedvezőnek számít. E téren - akár referencia árképzés céljából is - érdemes folyamatosan követni a U.S. Energy 
Information Administration éves előrejelző kiadványait, amely a világ legtermészetesebben fejlődő energiapiacának LCOE- és LACE-adatait mutatja be (URL1).

A geotermikus energiára alkalmazva ezt a számítási módszert, igen kedvező értékeket kaphatunk a beruházás gazdaságosságát tekintve. Ennek alapján, illetve Magyarország kedvező geotermikus tulajdonságainak köszönhetően is kap fontos szerepet a geotermia a 2050-ig kitekintő Nemzeti Energiastratégiában. Geotermikus potenciálunk nemzeti kincs, stratégiai készletként kezelhetjük. Hazai körülmények között elsősorban közvetlen hőtermelési célra éri meg kihasználni a geotermikus energiát, azonban távlati cél, hogy ne kizárólag erre legyen felhasználva. A legjobb megoldás energiahatékonysági szempontból a kapcsolt hö- és villamosenergia-termelés, illetve szintén egyre nagyobb számban megjelenhetnek a geotermikus távhörendszerek. Fontos, hogy az egyes esetekben jelenleg még magas költségek a technológiák fejlődésével gyors ütemben csökkenhetnek.

A Megújuló Energia Hasznosítási Cselekvési Terv (NCsT 2010-2020) szintén számol a geotermikus energiával. Az egy évtizeddel ezelőtt megfogalmazott célkitüzések szerint 2020-ra több mint háromszorosára nőhet a geotermikus energia fütési célú hasznosítása a 2010-es szinthez viszonyítva, és 2020-ig várhatóan megjelenik a geotermikus potenciál villamosenergia-termelésre történő hasznosítása is, ez utóbbi mintegy $57 \mathrm{MW}_{\mathrm{e}}$ tervezett felső müszaki technikai korlátú beépített teljesítménnyel (e cikk lezárásakor, 2019 öszén, bruttó 2,3 MW villamos teljesítménnyel müködik a turai geotermikus hö- és villamos erőmü, egyedüliként az országban). Ezeken túl 2020-ra a villamos energia, hütés-fütés, közlekedés szektorokban felhasznált megújuló energiahordozók 14\%-át teheti ki a geotermikus energia, összesen 16,43 PJ mennyiséggel. A tíz évvel ezelőtt megfogalmazott geotermikus energetikai célkitüzésekről ma azt lehet elmondani, hogy az előzetes adatok szerint 2018-ban primer belföldi felhasználásunk 0,5\%-a, összességében 5,56 PJ hasznosult ebből az energiaforrásból.

A 2011 és 2020 közti időszakra vonatkozó Nemzeti Környezettechnológiai Innovációs Stratégia is tartalmaz javaslatokat a geotermiához kapcsolódó innováció területén. Érdemes gondolkodni a geotermikus kútpárok fejlesztési, müszaki kérdéseinek megoldására irányuló mintaprojekteken. Szóba jöhetnek még az energiahatékonyságot növelö, a hulladékhőt is kihasználó integrált (kaszkád) höhasznosítási rendszerek, valamint a hévíz-visszasajtolás bizonyos technológiai és hidraulikai kérdései sem megoldottak.

A jelenlegi hazai helyzetről megállapítható, hogy a villamosenergia-termelésen kívül több módszert is alkalmazunk a geotermia hasznosítására. Alkalmazzuk távhőtermelésre, kapcsolt hö- és villamosenergia-termelésre, használati meleg víz készítésére, a geotermikus hőszivattyúk is terjednek, amelyeket akár fütésre, akár hütésre felhasználhatunk. Jelenleg még 10 PJ alatti a geotermikus energia hazai felhasználása, ami a felhasznált összes megújuló energián belül alacsony érték, de a 2020-as célok alapján ez változni fog. 
Érdemes megemlíteni az MBFSZ vezetésével megvalósuló Danube Region Leading Geothermal Energy (DARLINGE) pályázatot a Duna régió geotermikus erőforrásainak fenntartható hasznosításáról. A projektben tizenöt partner vesz részt hat országból, a cél a geotermikus energia felhasználásának előmozdítása a fütési szektorban a Pannon-medence déli részén, a határon átnyúló geotermikus rezervoárok komplex vizsgálata által.

\section{ÖSSZEGZÉS}

A geotermikus energia szempontjából a természeti adottságaink kedvezőek, s nemcsak a jelenben, de a távolabbi jövőben is adottak a hatékony geotermikusenergia-termelés feltételei. A tárolók nem csupán megfelelő hőmérsékletűek, s a felszínhez viszonylag közeliek, hanem a bennük tárolt óriási energiamennyiség hosszú időre fedezheti az energiaspektrum geotermikus forrásból kielégíthető hányadát. Természetesen nem eshetünk az egyoldalú és megalapozatlan optimizmus hibájába. Ugyanakkor a geotermikus energia hasznosításának szélesebb körủ elterjedését akadályozó tényezőkkel is számolnunk kell egy reálisabb kép kialakításához.

A geotermikus energia hasznosításának terjedése természeti adottságokban gazdag, de gazdaságilag hátrányos régiók fejlődését is magával hozhatja. A geotermikus energia kiaknázásának foglalkoztatást növelő szerepe van, az új szakmák és új munkahelyek az oktatás, a szakképzés, a mérnökképzés és mérnöktovábbképzés számára is feladatok sorát generálja. A geotermikus energia fokozott mértékủ hasznosítása nem érhető el pusztán müszaki kutatási, fejlesztési eszközökkel, átgondolt, előrelátó politikai döntések is szükségesek e cél eléréséhez.

Mindezek alapján megállapítható, hogy a geotermikus energia mint új, környezetbarát és gazdaságos energiaforrás alkalmas arra, hogy a magyar gazdaság egyik húzótényezője legyen.

IRODALOM

Tester, J. W. et al. (2006): The Future of Geothermal Energy. Cambridge, MA, USA: Massachusetts Institute of Technology

Tóth A. (2016): Magyarország geotermikus felmérése 2016. Budapest: Magyar Energetikai és Közmü-szabályozási Hivatal

URL1: Annual Energy Outlook: https://www.iea.org/ 